\title{
An Analysis of Students High Order Thinking Skills in Respiratory System Through a Scientific Approach
}

\author{
Ongguk Rotua Napitupulu \\ Student of Biology Education Department of Postgraduate \\ Program \\ Universitas Negeri Medan \\ Medan, Indonesia \\ Email : rotuanapit@gmail.com
}

\author{
Martina Restuati \\ Lecturer of Biology Education Department of Postgraduate \\ Program \\ Universitas Negeri Medan \\ Medan, Indonesia
}

\author{
Hasruddin \\ Lecturer of Biology Education Department of Postgraduate Program \\ Universitas Negeri Medan \\ Medan, Indonesia
}

\begin{abstract}
This study aims to analyze the high-order thinking skills through a scientific approach on respiration system. The population was eleventh grade with total about 440 students. Sample were taken by purposive sampling technique, namely as many as 6 classes with a total of 210 students. This research was a descriptive study which analyzes to make a systematic, factual, and accurate description of students' high-order thinking skills. The instrument for collect data was used cognitive tests at the C4-C6 level. The results showed that the students' high-order thinking skill in human respiratory system topic is categorized good. The percentage of graduation is $63.8 \%$ or 134 students.
\end{abstract}

Keywords-Higher Level Thinking, Scientific Approach

\section{INTRODUCTION}

Education is a process that is carried out consciously and planned to foster the development of human resources. By implementing education, people will become more qualified individuals. Education has contributed a lot to the development of knowledge and technology. Human require to continue to explore knowledge, not only master the material of knowledge but must be in harmony with skills or skills in order to be able to utilize the knowledge they have in everyday life [1].

The education process consists of 3 basic elements, namely input-process-output. The intended input is students with various backgrounds. The process is a learning activity which includes the giving and understanding of material by the teacher to students. Output is the result that has been achieved including cognitive, affective, and psychomotor [2]. At the present, the undeniable reality is that the main purpose of the education system is to teach students how to think. High-level cognitive skills, such as logical thinking and critical thinking, are basic skills in everyday life, regardless of academic achievement in schools [3].
Good cognitive ability is very important to be mastered by students, because when the cognitive value of students is high it means that learning done at school can be said to be successful. Scientific attitudes have a significant and positive relationship with students' cognitive achievement scores [4]. Scientific attitude is one of the main determinants of student achievement in knowledge and has become the quality of the main parameters of a student [5]. The study also revealed that the higher the scientific achievement the higher the scientific attitude of middle school students. The developing attitude of the interaction between individuals with the past and present environment, through the process of cognition of integration and consistency of attitude is formed into components of cognition, emotion, and tendency to act. After a fixed attitude will influence behavior directly, behavior will influence changes in the existing environment, and changes that occur will lead to changes in attitudes held [6].

Biology education emphasizes the provision of direct experience to develop competencies so that students are able to explore and understand the natural environment scientifically [7]. Teaching science to students should meets the criteria, which is in accordance with the nature of the science and in accordance with the knowledge of how students learn. By knowing the learning style of students, the teacher can adjust the teaching style to the needs of students, for example by using various teaching styles so that all students can get an effective way for him. Biology learning is directed to find out and act so that it can help students to gain a deeper understanding of the environment. Therefore, the approach applied in presenting biology learning is combining the experience of biological processes and understanding biological products in the form of direct experience. The area that gets the most attention in teaching programs is the cognitive domain (knowledge) [8]. Cognitive domains based on Bloom's taxonomy, which ranges from simple to the most 
complex, namely: remember, understand, apply, analyze, evaluate (evaluation), and create (creation) [9].

Based on the results of interviews with biology teachers in several public high schools throughout Medan, it is known that there are still students who still have a low sense of curiosity about respiration system materials. This can be seen when the teaching and learning process takes place, students seem unenthusiastic, when given the task to work on the questions and other tasks. The frequency of asking is also very low, seen when given the opportunity to ask only one or two people or not at all. Learning also seems boring; this is evidenced by the anxiety felt by students to be able to get out of the room even though time has not run out. The learning process that takes place is rigid so it does not support the development of students 'cognitive abilities and students' scientific attitudes. The achievement of students' completeness grades also varies. The respiratory system topic is quite important material, because the matter of respiration material is included in the National Examination and Joint Selection to Enter State Universities.

Biology is a subject included in the realm of science, one of the material contained in it is the respiratory system in humans. This material is considered difficult by students in the process of its application; this can be observed from the analysis of learning outcomes data in the 2016/2017 school year with a success rate that is still low. This can be seen from the evaluation value as much as $47 \%$ of students have not reached the KKM (Minimum Accomplishment Criteria) value set by the school which is 75 . The low achievement of the level of student learning completeness is influenced by conditions that are less conducive to learning and tends to the teacher center. Besides that, the lack of use of learning media is also believed to be one of the factors that lower the achievement of students' learning completeness.

The study of biology teachers at SMAN (Sekolah Menengah Atas Negeri) 5 Padang revealed that students had not achieved complete learning in biology, the KKM for biology learning set by the school was 83 . The low student learning outcomes were seen from the average value of biology daily tests of SMAN 5 Padang in class XI on the material of Human Respiratory System, the value obtained by students of the academic year 2012/2013 class XI IPA 3 (81.05) IPA 4 (71.88) and IPA 5 (69.88) This value indicates that the students' learning outcomes of SMAN 5 Padang are still below the KKM set by the school [10].

The results of observations from interviews with Ms. Enni Susanti as a biology teacher at SMA Negeri Medan 4 revealed that the results of students' cognitive abilities on certain submaterial in respiratory system obtained data (assessment results) were still below the KKM average of 75 . This was seen when the teaching and learning process takes place, students were less enthusiastic when given the task to work on other questions and tasks. In addition, the average score of UN (Ujian Nasional; National Examination) in SMA Negeri 4 Medan in the last three years was still low at 68 (2014), 67 (2015) and 70 (2016). Sub-material that was quite difficult to be taught in respiratory system was the mechanism of $\mathrm{O}_{2}$ and
$\mathrm{CO}_{2}$ exchange in cells. According to Ms. Alfrida Siregar and Ms. Mariana, the biology teacher said that sub-material that was quite difficult to teach was the mechanism of the process of respiration (binding to $\mathrm{O}_{2}$ and $\mathrm{CO}_{2}$ ), because it involves physiology. Whereas according to Ms. Tetty Hairani Hutasuhut that sub-material is quite difficult, namely respiration in animals, because animals varied, so the mechanism also varied, and students' scientific attitudes were also not much attention.

This study will analyze the students high order thining skill cognitive abilities of SMA Negeri (Public Senior High School) 4 Medan in respiratory system. In this study the cognitive abilities to be analyzed were divided into two categories, namely low-level thinking students (C1-C3) and high-level thinking students (C4-C6). Cognitive skill in high level as high order thinking skill Cognitive ability also emphasizes the ability of students to understand subject matter in the form of facts, concepts, principles, and procedures [11].

This research has purpose to find out the students cognitive ability in completing human respiratory system topic and their weakness as early as possible in order to be able to overcome it.

\section{RESEARCH METHOD}

This study is a descriptive study so that the data is analyzed to make a systematic, factual, and accurate description of students' high-level thinking abilities. The research conducted does not provide treatment, manipulation or alteration to independent variables, but describes a condition as it is. The cognitive process abilities on human respiratory system analyzed using a test kit that refers to Bloom's taxonomy. Data collect throught scientific method or aproach, which are observation the problem, formulate the problem, hypothesis, develop kit instrument test, validation of kit instrument, experiment by giving instrument to students, collect data and analysing, and make conclution.

This research was conducted at SMA Negeri 4 Medan, Indonesia. The population was all the eleventh students of SMA Negeri 4 Medan totaling 440 people. Samples were taken by purposive sampling technique, namely as many as 6 classes with a total of 210 students. The instrument for collecting data uses cognitive tests at the C4-C6 level. The instrument of cognitive ability used is a form of multiple choice tests (multiple choice, and test essays). The test used in this study contains 25 items of multiple choice questions with a total of five options and 10 test essay questions.

Data on cognitive abilities and scientific attitudes of students will be tabulated using Microsoft Excel 2010 done by searching for student grades and presented in descriptive form. Next to calculate the value of students' cognitive abilities can be done by:

$$
\begin{aligned}
& \mathrm{S}=\frac{\boldsymbol{K}}{N} \times 100 \\
& \text { Information: } \\
& \mathrm{S}=\text { Value of student high order thinking skill } \\
& \mathrm{R}=\text { Score obtained from the correct answer }
\end{aligned}
$$


$\mathrm{N}=$ Number of maximum scores from the test

So that the percentage of values obtained by students is grouped into the following criteria can be seen in Table 1 .

TABLE 1. CRITERIA FOR ASSESSING STUDENT COGNITIVE SKILLS

\begin{tabular}{|c|c|c|}
\hline No & Value Interval & Criteria \\
\hline 1 & $86-100$ & Very Good \\
\hline 2 & $76-85$ & Good \\
\hline 3 & $66-75$ & Moderate \\
\hline 4 & $56-65$ & Low \\
\hline 5 & 55 & Very Low \\
\hline
\end{tabular}

Source, Purwanto, 2013

Differences in cognitive abilities of students at low level of thinking (C1-C3) with high-level thinking (C4-C6) globally were conducted using non-parametric statistics using the SPSS22 application using the Man Whiteney test.

\section{RESULT AND DISCUSSION}

\section{A. Result of Research}

Based on the analysis of data, gained the student highorder thinking skills on human respiratory system is about 83.3 which is categorized good. Higher-order thinking skills in this study include analysing (C4), evaluating (C5) and creating (C6) and detail can be seen in Figure 1.

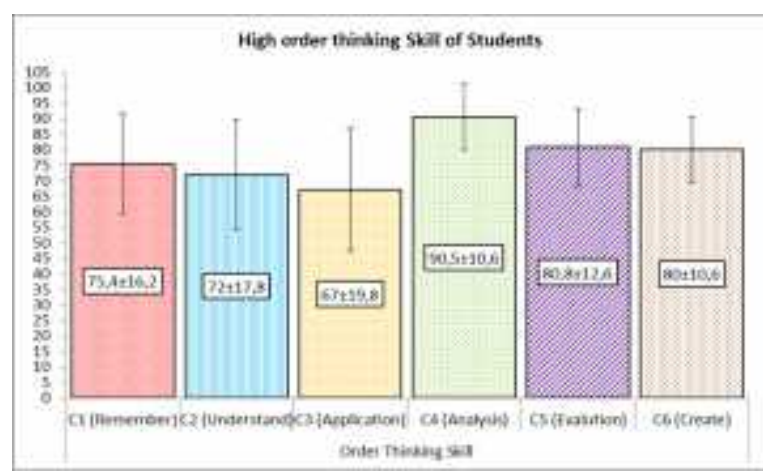

Fig. 1. Student high order thingking skill eleventh grade SMA Negeri 4 Medan.

From the graph in figure 1 can be seen that the students higher order thinking skill at the $\mathrm{C} 4$ level (analysing) is very good with highest scores of 90.5. In C5 (evaluation) and C6 (creativity) levels are 80.8 and 80 , which categorized good. Based on figure 1 by looking at the average value of students' high-level thinking skills and their standard deviations it is concluded that the percentage of graduations at the C5 level (evaluation) is $54.8 \%$ or as many as 115 students. Furthermore, at the $\mathrm{C} 4$ and $\mathrm{C} 5$ levels the standard deviation is 10.6 with a passing percentage of $63.8 \%$ or as many as 134 students.

Furthermore, in this study it can be seen the ability to think of high-level students per sub material on the respiratory system material. In this study the material of the respiratory system is divided into 6 sub-topic, namely: human respiratory organ; $\mathrm{O}_{2}$ and $\mathrm{CO}_{2}$ exchange mechanisms; lungs volume and capacities; respiratory frequency; respiratory diseases; and animal respiratory organ. The high order thinking skill of students in respiratory system subtopic can be seen in figure 2 .

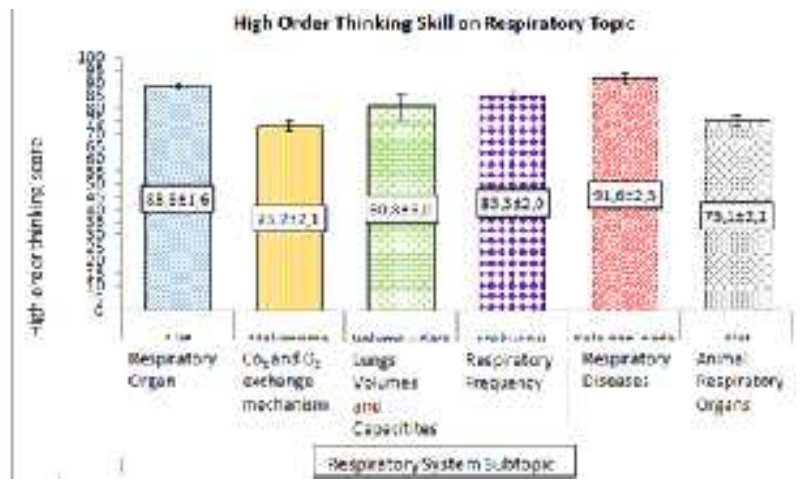

Fig. 2. Student high order thingking skill per indicator of human respiratory system

Based on figure 2, can be seen that the highest student score is in the respiratory diseases sub-topic that is 91.6 (very good), with a percentage of students at $73.8 \%$ or as many as 153 students. Then on human respiratory organs topic that is the 88.6 with a percentage of $65.5 \%$ or as many as 138 students and on the subject matter of respiratory frequency with score about 83.3 with a percentage of $65 \%$ or as many as 136 students. While the lowest student scores were on the $\mathrm{O}_{2}$ and $\mathrm{CO}_{2}$ exchange sub-material, namely about 73.2 (enough) with the percentage of students passing by $35.2 \%$ or only about 74 students. Followed by the score in animal respiratory organ is about 75.1 with a passing percentage of $40 \%$ or as many as 84 students

\section{B. Discussion}

The results of the data analysis, average value of students' high-level thinking ability tests on the respiratory system in class XI is about 83.3, included in either category. These results indicate that most students already have good highlevel thinking skills, especially in the respiratory system material. The results of this study is good, considering the ability to think at a higher level is an important thinking ability controlled by students. The important thinking skills should mastered by students, because the ability to think at a higher level is one of the stages of thinking that cannot be released from everyday life. Higher thinking abilities make anyone can think critically. The ability to think at a high level is the ability of students to connect, manipulate and transform knowledge and experience that they have to think critically and creatively in an effort to determine decisions and solve problems in new situations [13]. Higher-order thinking skills can be known from student high-level thinking skills at the level of analysis, evaluation, and creation [14].

The results in this study found that students' higher-order thinking skills were more dominant at the C4 level (analysis). This means that students of class XI MIA 4 Medan were accustomed to carrying out scientific activities, so their analytical skills were very good. In accordance with the statement above, analytical skills can also be built in practicum activities [15]. The ability of analysis is the ability 
of students in describing, separating, and linking things into parts. This result is a good thing, considering that analytical skills are very important among students. The ability of analysis refers to the ability to break down the material into its components or factors, and be able to understand the relationship between parts of one another so that the structure and rules can be better understood. The ability of analysis is the ability to think abstractly that is inseparable from conceptual knowledge [16].

Based on the subtopic on the respiratory system, the highlevel thinking ability of students was more dominant on the respiratory diseases topic, is about 91.6 , while the lowest was on the sub-material exchange mechanism of $\mathrm{O}_{2}$ and $\mathrm{CO}_{2}$ which was 73.2. These results indicate that students are weak in understanding the sub material regarding the $\mathrm{O}_{2}$ and $\mathrm{CO}_{2}$ exchange mechanism, this is in accordance with what was stated by Mrs. Alfrida Siregar and Ms. Mariana biology teacher at SMA Negeri 4 Medan. Likewise a research regarding students' understanding of oxygen and carbon dioxide binding reaction material obtained that the highest percentage of misconceptions was only $63.93 \%$ on indicators distinguishing the concepts of oxidation and reduction in terms of the incorporation and release of oxygen and a percentage of $4,92 \%$ of the indicators distinguish the concepts of oxidation and reduction [17]. Students do not understand the concept of oxidation reactions in binding or releasing oxygen is about $13.45 \%$.

This problem is allegedly due to misconceptions between teachers and students in teaching and understanding submaterial about the exchange mechanism of $\mathrm{O}_{2}$ and $\mathrm{CO}_{2}$, because the success of the teaching and learning process is not only determined by the teacher as a teacher but also determined by students in participating in learning. Misconceptions can occur when students are trying to shape knowledge by translating new experiences in the form of initial conceptions [18]. Students are expected to understand what is explained by the teacher, especially the core concepts in the material presented so that learning objectives are achieved. Two factors that influence students understanding of concepts, namely internal factors and external factors. Internal factors include student characteristics, attitudes toward the learning process, learning motivation, difficulty concentrating, and study habits. External factors such as the delivery of monoton lessons, the influence of the social environment, school curriculum, facilities and infrastructure that are not supportive [19]. In the future, teachers are able to enhance the ability of student to think in high-level on the respiratory system topic and especially on sub-material mechanism exchange of $\mathrm{O}_{2}$ and $\mathrm{CO}_{2}$, with various methods in learning.

\section{CONCLUSION}

This research obtained result that high order thinking skills of senior high school student of XI MIA class $c$ in SMA Negeri 4 Medan, namely 77, which is in the good category.

\section{REFERENCES}

[1] Rosa, O, "Analisis Kemampuan Siswa Kelas X pada Ranah Kognitif, Afektif dan Psikomotorik", Jurnal Pendidikan Omega. 1 (2), 62-78. Jurnal Biotik 4 (2), pp.16-29, 2015.

[2] Rizal, E \& Baktiar, S, "Hubungan antara Sikap, Kemandirian Belajar, dan Gaya Belajar dengan Hasil Belajar Kognitif Siswa", Jurnal Bioedukatika, 3 (2), pp.144-158, 2015.

[3] Gürol, A, "Determining The Reflective Thinking Skills Of Pre-Service Teachers In Learning and Teaching Process", Energy Education Science and Technology Part B: Social and Educational Studies, 3(3), pp. 387-402, 2011

[4] Ali \& Awan, "Atitude Towards Science and Its Relationship With Students' Achievement In Science Interdisciplinary", Journal of Contemporary Research In Business. 4 (1), pp.92-103, 2012.

[5] Abell, S.K \& Ledarman, N.G, Handbook of research on Science Education, New Jercy: Lowrence Erlbaum Associates, 2007.

[6] Bundu, P, Penilaian Keterampilan Proses Sains dan Sikap Ilmiah Siswa Dalam Pembelajaran Sains, Jakarta: Departemen Pendidikan Nasional, 2006.

[7] Depdiknas, Pendekatan Kontekstual (Contextual Teaching and Learning), 2003.

[8] Hasruddin \& Rezeqi S, "Analisis Pelaksanaan Praktikum Biologi dan Permasalahannya di SMA Negeri Sekabupaten Karo", Jurnal Tabularasa PPS UNIMED. 9 (1), pp.25-38, 2012.

[9] Anderson, L.W., D.R. Krathwohl., P.W. Airasian, A Taxonomy for Learning, Teaching, and Assesing, A Revision of Bloom's Taxonomy of Educational Objectives. New York: Addison Wesley Longman, Inc, 2001.

[10] Komisa., Nurhadi \& Maharani, A.D, "Pengaruh CD Interaktif pada Materi Sistem Pernapasan Terhadap Motivasi dan Hasil Belajar Siswa Kelas XI Semester II Tahun Pembelajaran 2013/2014 di SMAN 5 PADANG", Program Studi Pendidikan Biologi, Sekolah Tinggi Keguruan dan Ilmu Pendidikan (STKIP) PGRI Sumatera Barat. Padang, 2013.

[11] Arifin, Evaluasi Pendidikan, Jakarta: Bumi Aksara, 2009

[12] Purwanto, N, Prinsip-Prinsip dan Teknik Evaluasi Pengajaran, Bandung: PT Remaja Rosdakarya, 2013.

[13] Amalia, R, Penerapan Model Pembelajaran Pembuktian Untuk Meningkatkan Kemampuan Berpikir Matematis Tingkat Tinggi Siswa SMA. Skripsi, Universitas Pendidikan Indonesia, Bandung, 2013. unpublished

[14] Kawuwung, F., "Profil Guru, Pemahaman Kooperatif NHT, dan Kemampuan Berpikir Tingkat Tinggi di SMP Kabupaten Minahasa Utara". Jurnal El-hayah. 1 ( 4), pp.66-68, 2011.

[15] Wicaksono. A. G. C., "Perbandingan Kemampuan Kognitif dan Metakognitif Mahasiswa Dengan Gaya Belajar yang Berbeda", Media Penelitian Pendidikan. Vol.10 (2), 2016.

[16] Refiana, R., Jamal, M.A., \& Hartini, S, "Meningkatkan Kemampuan Analisis Siswa Kelas X MS3 SMAN 2 Banjarmasin melalui Pengajaran Langsung Bermetode Pemecahan Masalah", Jurnal Berkala Ilmiah Pendidikan, Universitas Lambung Mangkurat. 4 (1), pp.64-72, 2016

[17] Nurlela., Mawardi., \& Kurniati, T, "Kajian Miskonsepsi Siswa Melalui Tes Multiple Choice Menggunakan Certainty of Response Index (CRI) pada materi Reaksi reduksi oksidasi kelas X MIPA SMAN 1 Pontianak", Jurnal Ilmiah. Vol. 5 (2), 2017.

[18] National Science Teachers Association, Buku Pedoman Guru Biologi Edisi ke-4. Jakarta Barat: PT. Indeks, 2013.

[19] Abdurrahman, M, Pendidikan Bagi Anak Kesulitan Belajar, Jakarta: Rineka Cipta, 2003. 